\title{
Double-Ionization Energies of Fluorinated Benzene Molecules
}

\author{
W. J. Griffiths, * M. L. Langford, ${ }^{\dagger}$ and F. M. Harris \\ Mass Spectrometry Research Unit, University College of Swansea, Singleton Park, Swansea, United Kingdom
}

Results are reported of an experimental determination by double-charge transfer spectroscopy of the previously unknown double-ionization energies of the fluorinated benzene molecules $\mathrm{C}_{6} \mathrm{H}_{5} \mathrm{~F}, 1,2-\mathrm{C}_{6} \mathrm{H}_{4} \mathrm{~F}_{2}, 1,3-\mathrm{C}_{6} \mathrm{H}_{4} \mathrm{~F}_{2}, 1,4-\mathrm{C}_{6} \mathrm{H}_{4} \mathrm{~F}_{2}, 1,2,3-\mathrm{C}_{6} \mathrm{H}_{3} \mathrm{~F}_{3}, 1,2,4-\mathrm{C}_{6} \mathrm{H}_{3} \mathrm{~F}_{3}, 1,3,5-$ $\mathrm{C}_{6} \mathrm{H}_{3} \mathrm{~F}_{3}, 1,2,3,4-\mathrm{C}_{6} \mathrm{H}_{2} \mathrm{~F}_{4}, 1,2,3,5-\mathrm{C}_{6} \mathrm{H}_{2} \mathrm{~F}_{4}, 1,2,4,5-\mathrm{C}_{6} \mathrm{H}_{2} \mathrm{~F}_{4}$, and $\mathrm{C}_{6} \mathrm{HF}_{5}$. The data are remarkably similar; the lowest double-ionization energies for all the molecules are within \pm 0.5 of $25.7 \mathrm{eV}$, and the data for higher energies suggest that the distributions of electronic state energies for the dications of the molecules show only small variations. (I Am Soc Mass Spectrom 1993, 4, 513-518)

$\mathrm{O}$ ver the past twelve years, numerous experimental and theoretical studies [1-10] of the benzene dication have taken place. Recently, in this laboratory, the double-ionization energies required to form the dication in its ground and electronically excited states have been investigated [11] using double-charge transfer (DCT) spectroscopy [12]. A similar study of 10 chloro-substituted benzene molecules followed [13]. This program of research at Swansea has been extended to determine the double-ionization energies of 11 fluorinated benzene molecules of general formula $\mathrm{C}_{6} \mathrm{H}_{x} \mathrm{~F}_{y}$, where $x=1-5$ and $y=6-x$, the results of which are reported here. Unlike the situation for the benzene dication, little is known about the energies required to doubly ionize fluorinated benzene molecules or aboul the properlies of the resulting dications.

\section{Experimental}

In DCT spectroscopy, the translational energy losses associated with double-electron capture (DEC) reactions of high-velocity, singly charged, positive projectile ions, denoted here by $\mathrm{A}^{+}$, with the molecules $\mathrm{M}$ under investigation are measured. In the investigation reported here, the experiments were carried out using a $\mathrm{ZAB}-2 \mathrm{~F}$ reverse-geometry, double-focusing mass spectrometer [14] in which $6-\mathrm{keV} \mathrm{OH}^{+}$and $\mathrm{F}^{+}$projectile ions were generated by dissociative electron ionization of $\mathrm{H}_{2} \mathrm{O}$ and $\mathrm{CF}_{1}$, respectively. After mass selection, the ions interacted with fluorinated benzene

\footnotetext{
* Present address: Department of Physiological Chemistry, Karolinska Institutet, Box 60400, S-10401, Stockholm, Sweden.

+Present address: The Chemical Laboratory, The University of Kent, Canterbury, Kent CT2 7NH, UK.

Address reprint requests to F. M. Harris, Mass Spectrometry Research Unit, University College of Swansea, Singleton Park, Swansea SA2 8PP, UK
}

molecules contained in a collision gas cell at the intermediate focal point of the spectrometer. The translational energy spectrum of the $A^{-}$ions formed in $D E C$ reactions were recorded by scanning the voltages applied to the electric sector of the spectrometer. The energy loss scale was calibrated by running a similar experiment with one of the noble gases (argon, krypton, or xenon) in the cell. The relevant ionization energies of these are known [15], so the positions of the $\mathrm{A}^{-}$peaks in the resulting DCT spectrum effectively calibrate the energy loss scale. The calibration was found to be unaffected by which gas was used.

At low collision gas pressures, the DEC reaction

$$
\mathrm{A}^{+}+\mathrm{M} \rightarrow \mathrm{A}^{-}+\mathrm{M}^{2+}
$$

was far more important in generating $\mathrm{A}^{-}$ions than the two sequential single-electron capture (SEC) reactions

$$
\begin{aligned}
& \mathrm{A}^{+}+\mathrm{M} \rightarrow \mathrm{A}+\mathrm{M}^{+} \\
& \mathrm{A}+\mathrm{M} \rightarrow \mathrm{A}^{-}+\mathrm{M}^{+}
\end{aligned}
$$

Peaks in the $\mathrm{A}^{-}$ion spectrum are readily identified as being due to reaction 1 or reactions 2 and 3 by varying the collision gas pressure; $\mathrm{A}^{-}$ion yields from reaction 1 increase linearly with pressure, but for reactions 2 and 3 the yield increases quadratically with pressure.

Consider now the energetics of the reactions. In general, the energy required to form $\mathrm{M}^{2+}$ from $\mathrm{M}$, denoted by $I E_{2}(M)$, is larger than the energy released, $E\left(\mathrm{~A}^{+} \rightarrow \mathrm{A}^{-}\right)$, when charge inversion of $\mathrm{A}^{+}$occurs, so reaction 1 is endoergic. Thus, the translational energy $E_{n}$ of $\mathrm{A}^{-}$is less than $E_{0}$, that of $\mathrm{A}^{+}$, by an amount

$$
E_{0}-E_{n}=I E_{2}(\mathrm{M})-E\left(\mathrm{~A}^{+} \rightarrow \mathrm{A}^{-}\right)
$$


With a calibrant gas, say xenon, in the cell, the $\mathrm{A}^{-}$ions are generated with a translational energy $E_{c}$, where

$$
E_{0}-E_{c}=I E_{2}(\mathrm{Xe})-E\left(\mathrm{~A}^{+} \rightarrow \mathrm{A}^{-}\right)
$$

In practice, $E_{0}$ was kept constant throughout the experiment, and the $\mathrm{A}^{-}$ion currents were recorded as a function of the translational energy of $A^{-}$. From the positions of peaks in the spectra obtained with $M$ and then with xenon in the cell, the separation $E_{c}-E_{n}$ was measured, and $I E_{2}(M)$ determined from

$$
E_{c}-E_{n}=I E_{2}(\mathrm{M})-I E_{2}(\mathrm{Xe})
$$

If excited states of $\mathrm{M}^{2+}$ were populated, then other $\mathrm{A}^{-}$ ion peaks were seen in the spectra at lower values of $E_{n}$.

In a similar way, it is readily shown that for $\mathrm{A}$ ions formed by reactions 2 and 3 ,

$$
E_{c}-E_{n}=I E_{1}(\mathrm{M})+I E_{1}^{\prime}(\mathrm{M})-I E_{2}(\mathrm{Xe})
$$

where $I E_{1}(\mathrm{M})$ and $I E_{1}^{\prime}(\mathrm{M})$ are single-ionization energies of $M$ to, in general, different states of $\mathrm{M}^{+}$because the same state may not necessarily be populated in the two SEC reactions. Because $E_{c}-E_{n}$ can be measured and $I E_{2}(X e)$ is known, the sum of the single-ionization energies can be determined using eq 7 .

Metastable excited states of $\mathrm{OH}^{-}$and $\mathrm{F}^{-}$are known not to exist. The same is not true for $\mathrm{OH}^{+}$and $\mathrm{F}^{+}$ions formed by the method used in the present investigation. The possible effect of reactions of metaslable $\mathrm{OH}^{+}$and $\mathrm{F}^{+}$on DCT spectra has been discussed by Harris [16]. For $\mathrm{OH}^{+}$, the $a^{1} \Delta$ and $b^{1} \Sigma_{+}$states located at 2.15 and $3.55 \mathrm{eV}$, respectively, above the triplet ground state are known to have lifetimes long enough to enable the ions in those states to reach the collision gas cell in the ZAB-2F spectrometer. For $\mathrm{F}^{+}$, the ${ }^{1} \mathrm{D}_{2}$ and ${ }^{1} \mathrm{~S}$ states situated at 2.59 and $5.57 \mathrm{eV}$, respectively, are known to be metastable. The likely concentration of metastable ions in beams of $\mathrm{OH}^{+}$and $\mathrm{F}^{+}$is not large, and no evidence has been obtained of significant peaks in DCT spectra that could be ascribed to reactions of them.

\section{Results}

$\mathrm{C}_{6} \mathrm{H}_{5} \mathrm{~F}$

Figure 1 shows typical spectra obtained using $\mathrm{OH}^{+}$ and $\mathrm{F}^{+}$projectile ions, respectively. On the abscissa is plotted $I E_{2}\left(\mathrm{C}_{6} \mathrm{H}_{5} \mathrm{~F}\right)$, which is relevant only to the peaks marked with upper-case letters. The scale was established by making use of a calibration spectrum obtained with xenon (see Experimental). Consider the $\mathrm{OH}^{+} / \mathrm{C}_{6} \mathrm{H}_{5} \mathrm{~F}$ DCT spectrum first. Five peaks marked $a, b, A, B$, and $C$ are clearly evident. The heights of peaks $a$ and $b$ were found to increase quadratically with increase in $\mathrm{C}_{6} \mathrm{H}_{5} \mathrm{~F}$ pressure and were thus the

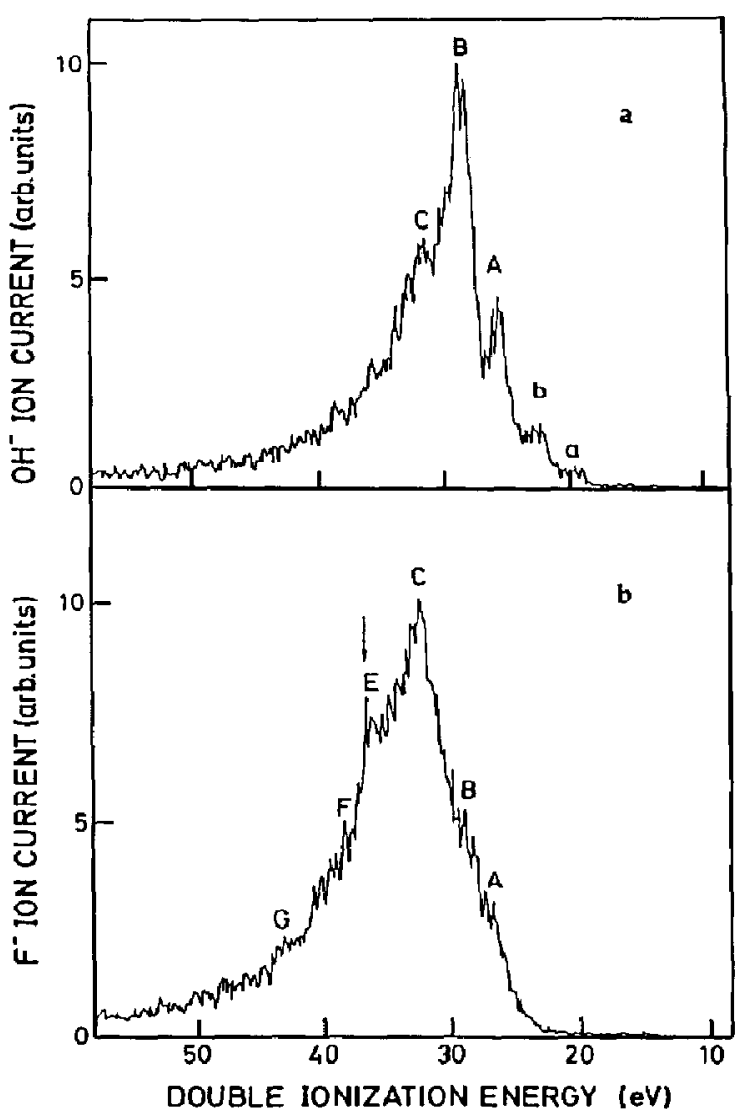

Figure 1. DCT spectra obtained when (a) $\mathrm{OH}^{+}$and (b) $\mathrm{F}^{+}$ projectile ions interacted with $\mathrm{C}_{6} \mathrm{H}_{5} \mathrm{~F}$ molecules.

result of reactions 2 and 3 . Their positions are readily understood in terms of the relevant single-ionization energies of $\mathrm{C}_{6} \mathrm{H}_{5} \mathrm{~F}$, which are known from a photoelectron spectrum [17].

The intensities of peaks $A-C$ in Figure 1a increased linearly with increase in pressure and were thus due to DEC reaction 1 . The double-ionization energies were determined from the positions of their maxima. This has been the common practice in previous DCT spectroscopy studies carried out here and in other laboratories. It yields vertical double-ionization energies and can be compared with the procedure to obtain vertical single-ionization energies from peak maxima in photoelectron spectra. The double-ionization energies associated with these peaks are $25.2 \pm 0.5,28.0 \pm 0.5$, and $31.2 \pm 0.8 \mathrm{eV}$, respectively, the uncertainties reflecting the difficulty associated with determining the position of the peak maxima. The tailing on the high-energy side of peak $\mathrm{C}$ is evidence of the formation of $\mathrm{C}_{6} \mathrm{H}_{5} \mathrm{~F}^{2+}$ ions in even higher energy states.

For Figure $1 \mathrm{~b}$, the effect of pressure variations established that all the features marked $C$ and $E-G$ were due to $\mathrm{F}^{-}$ions formed in DEC reactions. (The labeling 
of the peaks was chosen to allow the derived doubleionization energies to be positioned appropriately in Table 1, which is introduced below). It is now well established [16] that reaction windows of endoergicities exist for DEC reactions. A consequence of this is that, when using $\mathrm{F}^{+}$projectile ions, dication states are populated having higher energies than those populated when using $\mathrm{OH}^{+}$because $E\left(\mathrm{~F}^{+} \rightarrow \mathrm{F}^{-}\right)$is markedly larger than $E\left(\mathrm{OH}^{+} \rightarrow \mathrm{OH}^{-}\right)$. The position of peak $\mathrm{C}$ in Figure $1 \mathrm{~b}$ corresponds to a double-ionization energy of $31.2 \pm 0.5 \mathrm{eV}$, and the positions of the three shoulders $E, F$, and $G$ correspond to double-ionization energies of $35.1 \pm 0.8,38.4 \pm 1.0$, and $41.9 \pm 1.0 \mathrm{eV}$, respectively. Shoulder $E$ is very broad, and the derived energy of $35.1 \mathrm{eV}$ corresponds to the position indicated by the arrow. It is likely that this shoulder consists of a number of partially resolved peaks. Weak features marked $A$ and $B$ in Figure $1 b$ correspond to peaks $A$ and $B$, respectively, in Figure la.

Because of the high velocity of the projectile ions, DEC reactions are fast, and thus the double-ionization energies measured are vertical. Evidence exists that suggests that triplet states of the dications were populated. Spin conservation has been shown to apply for DEC reactions of $\mathrm{F}^{+}$and/or $\mathrm{OH}^{+}$projectile ions with numerous smaller molecules $\left(\mathrm{CO}_{2}, \mathrm{OCS}, \mathrm{CS}_{2}[18,19]\right.$, $\mathrm{NH}_{3}[20,21], \mathrm{N}_{2} \mathrm{O}$ [22], $\mathrm{C}_{2} \mathrm{H}_{2}$ [23], $\mathrm{C}_{2} \mathrm{H}_{4}$ [24], and
$\mathrm{C}_{2} \mathrm{H}_{6}$ [25]), resulting in the populating of triplet states of the dications. Also, comparison of experimental results with theoretical predictions suggests that triplet states of $\mathrm{C}_{6} \mathrm{H}_{6}^{2+}$ were populated in a DCT spectroscopy study [11] using these projectile ions.

The double-ionization energies of $\mathrm{C}_{6} \mathrm{H}_{5} \mathrm{~F}$ are listed in Table 1 together with the results for the other fluorinated benzene molecules studied. Also included in Table 1 are the results for $\mathrm{C}_{6} \mathrm{~F}_{6}$ [26] obtained previously in this laboratory.

$\mathrm{C}_{6} \mathrm{H}_{4} \mathrm{~F}_{2}$

The DCT spectra for the three molecules $1,2-\mathrm{C}_{6} \mathrm{H}_{4} \mathrm{~F}_{2}$, $1,3-\mathrm{C}_{6} \mathrm{H}_{4} \mathrm{~F}_{2}$, and $1,4-\mathrm{C}_{6} \mathrm{H}_{4} \mathrm{~F}_{2}$ are similar, and a typical pair for $1,4-\mathrm{C}_{6} \mathrm{H}_{4} \mathrm{~F}_{2}$ is shown in Figure 2. The peaks labeled with lower-case letters are due to SEC reactions 2 and 3 , and those marked with uppercase letters are due to DEC reaction 1 . The doubleionization energies derived from the spectra of the three molecules are listed in Table 1.

$\mathrm{C}_{6} \mathrm{H}_{3} \mathrm{~F}_{3}$

A pair of spectra typical of those obtained for 1,2,3$\mathrm{C}_{6} \mathrm{H}_{3} \mathrm{~F}_{3}, 1,2,4-\mathrm{C}_{6} \mathrm{H}_{3} \mathrm{~F}_{3}$, and $1,3,5-\mathrm{C}_{6} \mathrm{H}_{3} \mathrm{~F}_{3}$ are shown in Figure 3 . Peaks $A-E$ are due to DEC reactions, and the

Table 1. Double-ionization energies (eV) derived from the positions of peaks in double-charge transfer spectra

\begin{tabular}{|c|c|c|c|c|c|c|c|}
\hline \multirow[b]{2}{*}{ Molecule } & \multirow[b]{2}{*}{ Projectile } & \multicolumn{6}{|c|}{ Peak } \\
\hline & & A & $B$ & $\mathrm{C}$ & $\mathrm{D}$ & $\mathbf{E}$ & $F$ \\
\hline \multirow[t]{2}{*}{$\mathrm{C}_{6} \mathrm{H}_{5} \mathrm{~F}$} & $\mathrm{OH}^{+}$ & $25.2 \pm 0.5$ & $28.0 \pm 0.5$ & $31.2 \pm 0.8$ & & & \\
\hline & $\mathbf{F}^{\prime}$ & & & $31.2 \neq 0.5$ & & $35.1 \pm 0.8$ & $38.4 \pm 7.0$ \\
\hline \multirow[t]{2}{*}{$1.2-C_{6} H_{4} F_{2}$} & $\mathrm{OH}^{+}$ & $25.4 \pm 0.5$ & $28.2 \pm 0.5$ & & & & \\
\hline & $\mathbf{F}^{+}$ & & $29.0 \pm 1.0$ & $31.6 \pm 0.5$ & $33.3 \pm 0.8$ & $36.0 \pm 0.8$ & $38.7 \pm 1.0$ \\
\hline \multirow[t]{2}{*}{$1,3-\mathrm{C}_{6} \mathrm{H}_{4} \mathrm{~F}_{2}$} & $\mathrm{OH}^{+}$ & $25.3 \pm 0.5$ & $28.3 \pm 0.5$ & $31.2 \pm 0.5$ & & & \\
\hline & $\mathbf{F}^{+}$ & & & $31.2 \pm 0.8$ & $32.7 \pm 0.8$ & $34.5 \pm 0.8$ & $37.0 \pm 1.0$ \\
\hline \multirow[t]{2}{*}{$1,4-\mathrm{C}_{6} \mathrm{H}_{4} \mathrm{~F}_{2}$} & $\mathrm{OH}^{+}$ & $25.5 \pm 0.5$ & $28.4 \pm 0.5$ & $30.5 \pm 0.8$ & $33.0 \pm 1.0$ & & \\
\hline & $F^{1}$ & & $28.4 \pm 0.5$ & $31.0 \pm 0.5$ & $33.4 \pm 0.5$ & $35.9 \pm 1.0$ & \\
\hline \multirow[t]{2}{*}{$1,2,3-C_{6} H_{3} F_{3}$} & $\mathrm{OH}^{+}$ & $25.8 \pm 0.5$ & $28.8 \pm 0.5$ & $31.3 \pm 0.8$ & & & \\
\hline & $\mathbf{F}^{+}$ & & $28.7 \pm 1.0$ & $31.9 \pm 0.5$ & $33.8 \pm 1.0$ & & \\
\hline \multirow[t]{2}{*}{$1,2,4-\mathrm{C}_{6} \mathrm{H}_{3} \mathrm{~F}_{3}$} & $\mathrm{OH}^{+}$ & $25.8 \pm 0.5$ & $28.9 \pm 0.5$ & $31.3 \pm 0.8$ & $34.4 \pm 1.0$ & & \\
\hline & $\mathbf{F}^{+}$ & & $29.0 \pm 1.0$ & $31.5 \pm 0.5$ & $33.7 \pm 0.8$ & $37.2 \pm 0.8$ & \\
\hline \multirow[t]{2}{*}{$1,3,5-C_{6} H_{3} F_{3}$} & $\mathrm{OH}^{+}$ & $25.3 \pm 0.5$ & $28.6 \pm 0.5$ & $31.2 \pm 0.8$ & $33.7 \pm 1.0$ & & \\
\hline & $\mathrm{F}^{+}$ & & $29.7 \pm 0.8$ & $32.1 \pm 0.8$ & $34.4 \pm 1.0$ & $36.8 \pm 1.0$ & \\
\hline \multirow[t]{2}{*}{$1,2,3,4-\mathrm{C}_{6} \mathrm{H}_{2} \mathrm{~F}_{4}$} & $\mathrm{OH}^{+}$ & $25.8 \pm 0.5$ & $28.7 \pm 0.5$ & & & & \\
\hline & $\mathbf{F}^{+}$ & & $29.3+0.5$ & $31.9+0.8$ & $34.6+0.8$ & $37.4+1.0$ & \\
\hline \multirow[t]{2}{*}{$1,2,3,5-\mathrm{C}_{6} \mathrm{H}_{2} \mathrm{~F}_{4}$} & $\mathrm{OH}^{+}$ & $25.7 \pm 0.5$ & $28.7 \pm 0.8$ & $30.9 \pm 1.0$ & $32.7 \pm 1.0$ & & \\
\hline & $\mathbf{F}^{+}$ & & & $31.8 \pm 0.8$ & $33.3 \pm 1.0$ & & \\
\hline \multirow{2}{*}{$1,2,4,5-\mathrm{C}_{6} \mathrm{H}_{2} \mathrm{~F}_{4}$} & $\mathrm{OH}^{\prime}$ & $26.7 \pm 0.6$ & $28.8 \pm 0.8$ & $30.9 \pm 1.0$ & & & \\
\hline & $\mathbf{F}^{+}$ & & & $30.9 \pm 0.8$ & & & \\
\hline $\mathrm{C}_{6} \mathrm{HF}_{5}$ & $\begin{array}{r}\mathrm{OH}^{+} \\
\mathbf{F}^{+}\end{array}$ & $26.0 \pm 0.5$ & $28.6 \pm 0.5$ & $30.4 \pm 0.8$ & $\begin{array}{l}31.6 \pm 1.0 \\
32.2 \pm 0.8\end{array}$ & $33.6 \pm 1.0$ & \\
\hline \multirow[t]{2}{*}{$\mathrm{C}_{6} \mathrm{~F}_{6}{ }^{a}$} & $\mathrm{OH}^{+}$ & $26.3 \pm 0.5$ & $28.4 \pm 0.5$ & $29.2 \pm 0.5$ & $31.5 \pm 0.8$ & & \\
\hline & $\mathbf{F}^{+}$ & & & & $32.8 \pm 0.8$ & & \\
\hline
\end{tabular}

\footnotetext{
Data from ref 26
} 


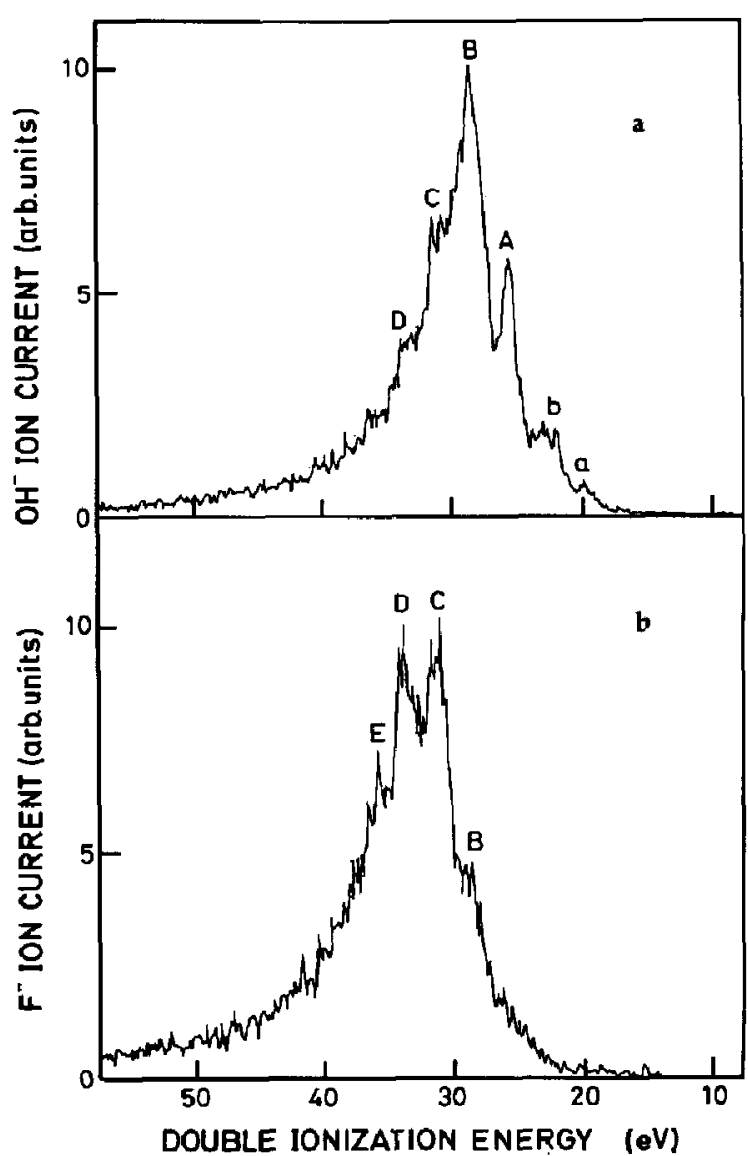

Figure 2. DCT spectra obtained when (a) $\mathrm{OH}^{+}$and (b) $\mathrm{F}^{+}$ projectile ions interacted with $1,4-\mathrm{C}_{6} \mathrm{H}_{4} \mathrm{~F}_{2}$ molecules.

values of double-ionization energies determined from their positions are listed in Table 1.

$\mathrm{C}_{6} \mathrm{H}_{2} \mathrm{~F}_{4}$

A typical pair of spectra for $1,2,3,4-\mathrm{C}_{6} \mathrm{H}_{2} \mathrm{~F}_{4}, 1,2,3,5-$ $\mathrm{C}_{6} \mathrm{H}_{2} \mathrm{~F}_{4}$, and $1,2,4,5-\mathrm{C}_{6} \mathrm{H}_{2} \mathrm{~F}_{4}$ are shown in Figure 4. The double-ionization energies of the peaks associated with $\mathrm{DEC}$ reactions are listed in Table 1.

$\mathrm{C}_{6} \mathrm{HF}_{5}$

A typical pair of spectra are shown in Figure 5, and the double-ionization energies determined for this molecule are shown in Table 1.

\section{Discussion}

Examination of the data in Table 1 reveals that the results in each column are remarkably similar. The positions of peaks labeled $A$ in the $\mathrm{OH}^{+}$DCT spectra were in general measured quite accurately because the

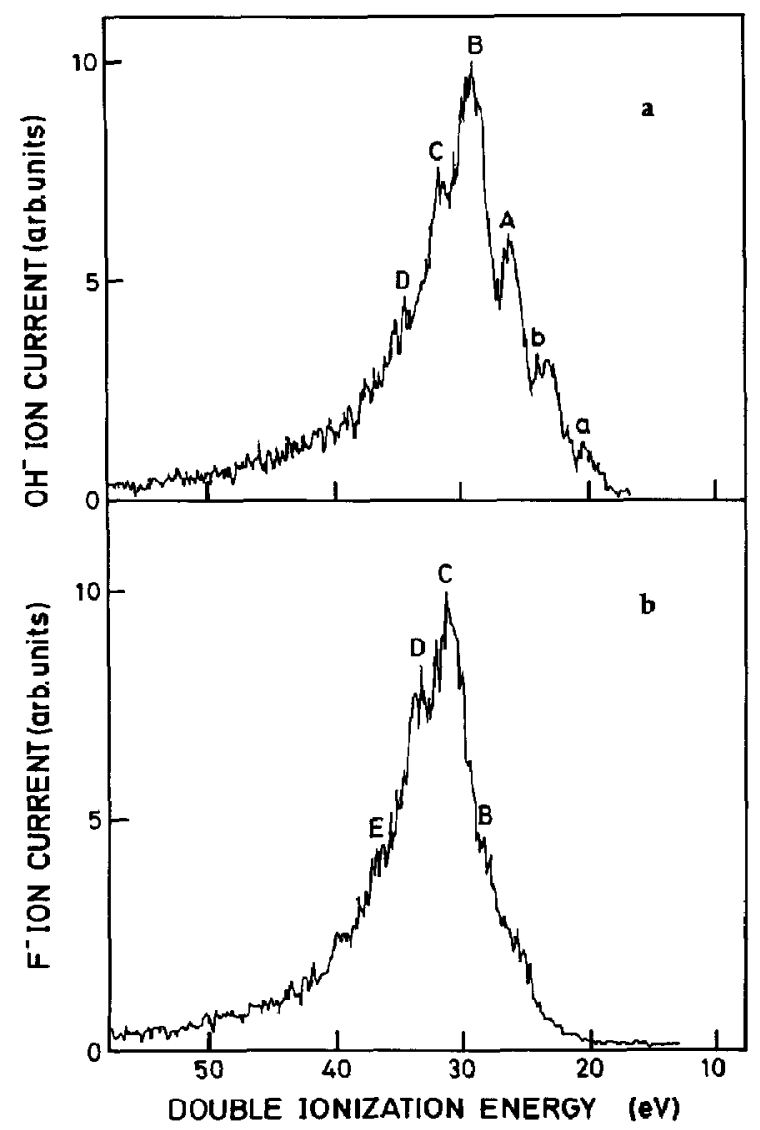

Figure 3. DCT spectra obtained when (a) $\mathrm{OH}^{+}$and (b) $\mathrm{F}^{+}$ projectile ions interacted with $1,2,4-C_{6} \mathrm{H}_{3} \mathrm{~F}_{3}$ molecules.

peaks are reasonably intense and well resolved. The average double-ionization energy determined from these peaks for all of the molecules studied is $25.7 \mathrm{eV}$, which is within $\pm 0.5 \mathrm{eV}$ of all the lowest double-ionization energies in Table 1. A trend is observed, however, suggesting that the double-ionization energy increases as the number of fluorine atoms in the molecule increases. Peaks labeled $\mathrm{B}$ in the $\mathrm{OH}^{+} \mathrm{DCT}$ spectra are in general also intense and well resolved; the average of the double-ionization energies derived from them is $28.5 \mathrm{eV}$, with all of the results within $\pm 0.5 \mathrm{eV}$. Similar data derived for peaks $\mathrm{C}, \mathrm{D}$, and $\mathrm{E}$ are $31.1 \pm 0.8,-0.9$ $\mathrm{eV}, 32.2 \pm 1.4_{r}-1.4 \mathrm{eV}$, and $35.8 \pm 1.6,-2.2 \mathrm{cV}$, respec tively. When allowance is made for the larger uncertainties in determining the positions of these three peaks, it is reasonable to assume that the state distributions of all the dications investigated in the present study are similar.

Some insight into which electrons are removed in the double ionization of the molecules studied can be obtained by considering the results of theoretical studies of the double ionization of $\mathrm{C}_{6} \mathrm{H}_{6}$ [10] and $\mathrm{C}_{6} \mathrm{~F}_{6}$ [26]. The lowest double-ionization energy measured for 


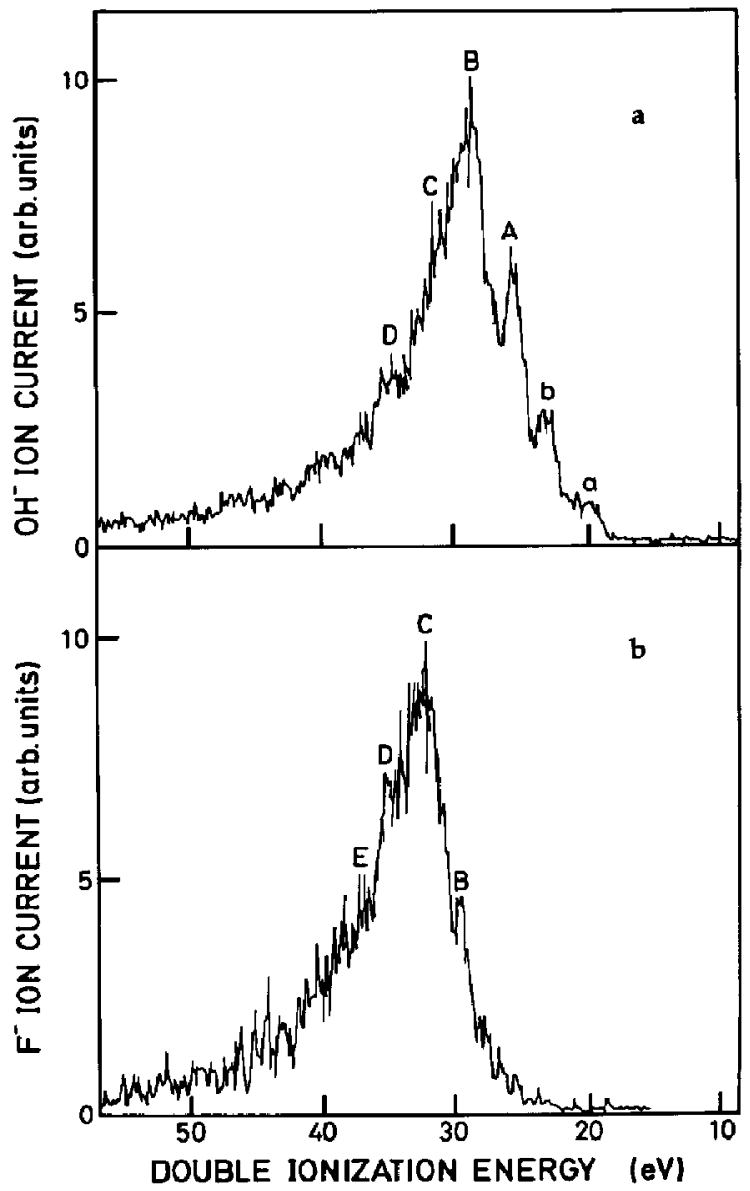

Figure 4. DCT spectra obtained when (a) $\mathrm{OH}^{+}$and (b) $\mathrm{F}^{+}$ projectile ions interacted with $1,2,3,4-\mathrm{C}_{6} \mathrm{H}_{2} \mathrm{~F}_{4}$ molecules.

$\mathrm{C}_{6} \mathrm{H}_{6}$ is $24.6 \pm 0.5 \mathrm{eV}$ [11]. Making use of the data from the theoretical study [10], the peak corresponding to this energy was interpreted [11] to be the result of the formation of $\mathrm{C}_{6} \mathrm{H}_{6}^{2+}$ in its ground triplet state $\left({ }^{3} \mathrm{~A}_{28}\right)$, which corresponds to the removal of two electrons from the outermost $\pi$-orbital (i.e., $1 \mathbf{e}_{1 \mathrm{~g}}^{-2}$ ). The lowest energy of $26.3 \mathrm{eV}$ for $\mathrm{C}_{6} \mathrm{~F}_{6}^{2+}$ has been assigned [26] to the ground triplet state $\left({ }^{3} \mathrm{~A}_{1 g}\right)$ populated by the removal of two electrons from the outermost $\pi$-orbital $\left(2 e_{1 g}\right)$ of $\mathrm{C}_{6} \mathrm{~F}_{6}$. The next two peaks in the spectra for $\mathrm{C}_{6} \mathrm{H}_{6}$ and $\mathrm{C}_{6} \mathrm{~F}_{6}$ correspond to double-ionization energies of 27.3 and $28.4 \mathrm{eV}$, respectively. Each is due to the populating of two states and results from removal of electrons from (1) the two outermost $\pi$-orbitals and (2) the outermost $\pi$-and $\sigma$-orbitals. Other peaks in the $\mathrm{C}_{6} \mathrm{H}_{6}$ and $\mathrm{C}_{6} \mathrm{~F}_{6}$ spectra are interpreted as due to populating of several dication states, the electrons being removed from inner orbitals of the molecules. It is likely that the DCT spectra for the $\mathrm{C}_{6} \mathrm{H}_{x} \mathrm{~F}_{y}$ molecules studied here result from ionization processes similar to those predicted $[10,26]$ for $\mathrm{C}_{6} \mathrm{H}_{6}$ and $\mathrm{C}_{6} \mathrm{~F}_{6}$.

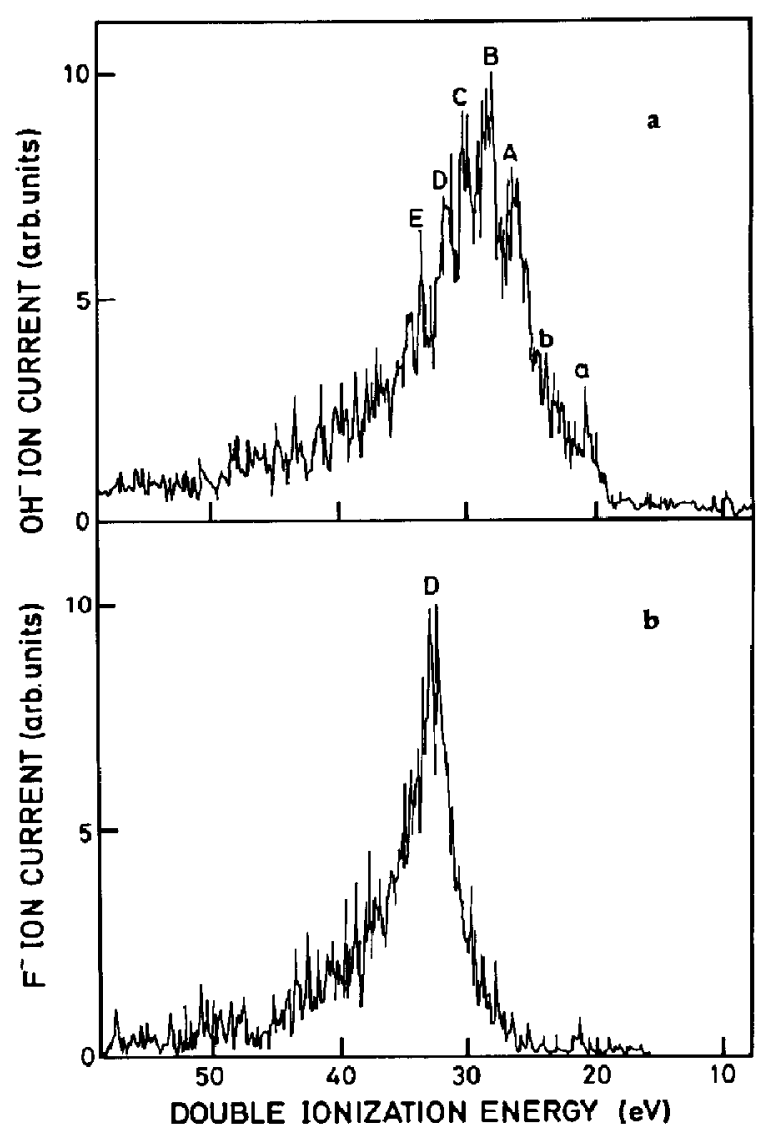

Figure 5. DCT spectra obtained when (a) $\mathrm{OH}^{+}$and (b) $\mathrm{F}^{+}$ projectile ions interacted with $\mathrm{C}_{6} \mathrm{HF}_{5}$ molecules.

\section{Acknowledgment}

M. L. Langford is grateful to the Science and Engineering Research Council for financial support.

\section{References}

1. Ast, T. Adn. Mass Spectrom. 1980, 8A, 855.

2. Mathur, B. P.; Burgess, E. M.; Bostwick, D. E.; Moran, T. F. Org. Mass Spectrom. 1981, 16, 92.

3. Lammertsa, K.; Schleyer, P. v. R. J. Am. Chem. Soc. 1983, 105, 1049.

4. Dewar, M. J. S.; Holloway, M. K. J. Am. Chem. Soc. 1984, 106, 6619.

5. Appling, J. R.; Burdick, G. W.; Hayward, M. J.; Abbey, L. E.; Moran, T. F. J. Phys. Chem. 1985, 89, 13.

6. Kingston, R. G.; Guilhaus, M.; Brenton, A. G.; Beynon, J. H. Org. Mass Spectrmm. 1985, 20, 406.

7. Kingston, E. E.; Beynon, J. H.; Ast, T.; Flammang, R.; Maquestiau, A. Org. Mass Spectrom. 1988, $20,546$.

8. Richardson, P. I.; Eland, J. H. D.; Lablanquie, P. Org. Mass Spectrom. 1986, 21, 289.

9. Vekey, K.; Brenton, A. G.; Beynon, J. H. Org. Mass Spectrom. $1988,23,31$.

10. Tarantelli, F.; Sgamellotti, A.; Cederbaum, L. S.; Schirmer, J. J. Chem. Phys. 1987, 86, 2201. 
11. Griffiths, W. J.; Harris, F. M. Chem. Phys. 1991, 157, 299.

12. Appell, J;; Durup, J.; Fehsenfeld, F. C.; Fournier, P. J. Phys. B. 1974, 7, 406 .

13. Harris, F. M.; Jackson, P. J.; Rontree, J. A.; Griffiths, W. J. Org. Mass Spectrom. 1992, 27, 261.

14. Morgan, R. P.; Beynon, J. H.; Bateman, R. H.; Green, B. N. Int. J. Mass Spectrom. Ion Phys. 1978, 28, 171.

15. Moore, C. Atomic Energy Levels; National Bureau of Standards: Washington, DC, 1949.

16. Harris, F. M. Int. J. Mass Spectrom. Ion Processes 1992, 120, 1.

17. Streets, D. G.; Ceasar, G. P. Mol. Phys. 1973, 26, 1037.

18. Griffiths, W. J.; Harris, F. M. Int. J. Mass Spectrom. Ion Processes $1989,87,349$.

19. Langford, M. L.; Harris, F. M.; Reid, C. J.; Ballantine, J. A.; Parry, D. E. Chemt. Phys. 1991, 149, 445.
20. Griffiths, W. J.; Harris, F. M. Rapid Commun. Mass Spectrom. $1990,4,366$

21. Langford, M. L.; Harris, F. M.; Fournier, P. G.; Fournicr, J. Int. J. Mass Spectrom. Ion Processes 1992, 116, 53.

22. Harris, F. M.; Reid, C. J; Ballantine, J. A.; Parry, D. E. 1. Chem. Soc. Faraday Trans. 1991, 87, 1681.

23. Andrews, S. R.; Harris, F. M.; Parry, D. E. Chem. Phys. 1992 $166,69$.

24. Griffiths, W. J.; Harris, F. M. Int. J. Mass Spectrom. Ion ProCesses 1992, 122, 321.

25. Griffiths, W. J.; Harris, F. M.; Andrews, S. R.; Parry, D. E. Int. 1. Mass Spectrom. Ion Processes 1991, 100, 135

26. Griffiths, W. J,; Svensson, S.; Naves de Brito, A.; Correia, N.; Langford, M. L.; Harris, F. M. J. Chem. Soc. Faraday Trans., in press. 